\title{
PERSIUS ON GREEKS, JEWS AND BARBARIANS
}

\author{
J C Zietsman (University of Stellenbosch)
}

The range of multicultural references in the satires of Persius falls into three groups. This paper will discuss a representative selection of the poet's most obvious and most significant references to Greeks, Jews and other population groups which I collectively call barbarians. The vast majority of these references in Persius' satires relate to Greeks, there is only one reference to Jews, and three references to barbarians will be discussed briefly.

\section{Persius on Greeks}

Two categories of Greek vocabulary and references to Greeks in Roman satire can clearly be distinguished (Rudd 1986:165). The first category is reserved for words which convey some special emphasis or nuance (whether for abusive, sarcastic or humorous effect). Included in this category is also the use of Greek proper names, occupations, traditions and references to social status to convey anything from sometimes extreme hostility to ridicule and caricature. An example of this is Persius 4.3, where Alcibiades (c. 450-404 B.C., the son of Cleinias, an Athenian general and statesman), who was brought up in the household of Pericles, is mockingly addressed as magni pupille Pericli, "ward of the mighty Pericles". Although Alcibiades showed himself to be outstandingly capable as a politician and later as a military leader, his personal ambition and the excesses of his private life aroused the distrust of the Athenians. This periphrasis identifies Alcibiades and at the same time hints at the advantage he hopes to gain from Pericles' guardianship (Harvey 1981:106; Lee \& Barr 1987:119).

A famous fragment from Lucilius illustrates that even the use of Greek as a language could be inappropriate. In 87-93 Lucilius describes a certain Titus Albucius who overdid the use of Greek to such an extent that he even preferred to be addressed as a Greek, at least when he was in Athens. So, when Scaevola met him in Athens in 121 B.C., he said: "When you approach me, I as praetor greet you in Athens in Greek, as you have preferred. 'Chaere (Bonjour), Tite!', I say." Much to Albucius' annoyance, Scaevola's whole retinue echoed with "Chaere, Tite!" (Rudd 1986:169).

The second category includes words of which the function appears to be neutral. Since a discussion of this category is not the principal aim of this paper, one example will suffice: in 3.118 Persius mentions Orestes to illustrate his argument that the ordinary man who does not have a philosophical education, is in fact more insane than Orestes, who was commonly used as the outstanding mythological example of insanity (Jenkinson 1980:82; Morford 1984:49; Lee \& Barr 1987:118)1:

1 Varro wrote a book on insanity called Orestes vel de insania (Gellius $N A$ 13.4.1). 
dicisque facisque quod ipse

non sani esse hominis non sanus iuret Orestes. ${ }^{2}$

You say and do what even mad Orestes would swear was lunacy.

$$
\text { (3.117-118) }
$$

Juvenal, who hates the Greeks (see e.g. Satire 3), mentions twenty-six Greek historical figures of whom seventeen are given favourable or at least neutral mention. These include statesmen, artists, and philosophers in usually brief references without any retrospective animosity (see Rudd 1986:184).

\section{Persius on barbarians}

Before continuing the discussion of Persius' references to Greeks, this is probably the appropriate place for mentioning that most of the poet's few references involving barbarians also seem not to have any satiric colouring and therefore fall in this category. One example is Sa. 3.39-41:

anne magis Siculi gemuerunt aera iuvenci et magis auratis pendens laquearibus ensis purpureas subter cervices terruit?

Were the bellows which came from Sicily's bronze bull more terrifying, or did the sword, hung from a gilded ceiling, cause more fear to the purple neck beneath?

These lines refer to Phalaris, tyrant of Agrigentum (6th century B.C.) ${ }^{3}$ and Dionysius I, tyrant of Syracuse (c.430-367 B.C.) ${ }^{4}$, who are both common examples in ancient moral discourse (Horace Ep. 1.2.58f., 1.16.73ff.; Carm. 3.1.17ff., 3.3.3). Persius is not satirizing the tyrants but he is underlining his argument that awareness of one's moral depravity is a torture more terrible than any devised by tyrants (Harvey 1981:88).

Similarly, the reference to Cappadocas ... pinguis ("fat Cappadocian slaves") in Sat. 6.77 underlines the greed of the rich slave-dealers and prospective buyers who slap the slaves in order to demonstrate and explore their condition. (Cappadocia in Asia Minor was such a famous source of slaves that "Cappadocian slaves" became proverbial.) Persius was not interested in slaves or the kind of life they lived: the

2 I have used Clausen's edition (1959) for quotations from Persius. Some translations are my own; others have been taken or adapted from Jenkinson (1980), Lee \& Barr (1987), or the Penguin edition (1973) by Rudd.

3 Phalaris roasted his victims in a bronze bull that is here said to "bellow" to the screams of those roasting inside it (Pliny HN 34.89).

4 Dionysius ordered that a sword should be suspended by a single hair over the head of Damocles to demonstrate that the life of a monarch was not as comfortable as he had suggested. 
word servus never appears in his satires (Lee \& Barr 1987:168 Sat. 6.77; Rudd 1986:144).

One exception to the poet's neutral references to barbarians is Sat. 3.53-54 where Persius refers to the "trousered Persians" (bracatis inlita Medis) appearing in a fresco of the battle of Marathon that was painted in the Stoa Poikile. Although bracatis describes the typical Persian clothing (therefore befitting the barbarians), its combination with inlita results in a comically grotesque phrase: inlita ("smeared" or "spread") 5 is contemptuously substituted for picta ("painted").

A very interesting reference to barbarians which does not fall into any of these two categories mentions Caligula's German victory in a highly sarcastic tone (Persius 6.43-44):

\section{missa est a Caesare laurus insignem ob cladem Germanae pubis.}

A laurel has come from Caesar to announce his triumph over the German tribes.

Suetonius (Calig. 43, 47) and Tacitus (Germ. 37) relate the fiasco of this campaign; Caligula himself, who had to hire prisoners and dress up Gauls as Germans in the triumphal procession, is the object of the satirist's ridicule rather than the barbarians (Morford 1984:116): the poet's sarcasm is heightened by insignem, "distinguished", "remarkable", as well as by Germanae pubis, a type of periphrasis greatly favoured in elevated poetry (Harvey 1981:195). By the way, this anachronistic reference to Caligula's triumph of A.D. 40 is a very typical feature of satire: Persius could hardly have mocked Nero! (Harvey 1981:195).

Returning to Greek vocabulary and references to Greeks in Roman satire, this example is an important reminder that Greek influence went far beyond the purely linguistic usages of Roman satirists. Although philhellenism was a key element in the Scipionic circle who played an important part in creating the conditions that helped to shape satire as a genre, it was certainly not their prerogative: the Greek world made its impact on every occupation from the humblest to the most refined (Rudd 1986:162-165). Hundreds of Greeks (many of them prisoners of war) were employed as teachers; many more were doctors, masons, artists. Livy (39.6.7-9) describes how "female flute-players and harpists and other types of festive entertainment became a feature of banquets; and from now on greater care and expense were bestowed on the banquets themselves. The cook, who in earlier times was regarded and treated as the cheapest kind of slave, began to be valued more highly, and what had once been a menial occupation came to be viewed as an art." In the words of Horace: Graecia capta ferum victorem cepit et artis / intulit agresti Latio ("Conquered Greece had taken her rough conquerer captive and brought the arts to rustic Latium", Ep. 2.1.156-157).

5 Lewis and Short, s.v. illino. 
But although Roman society was permeated with the ideas of philhellenism, there were limits to the acceptability of Greek and aspects of Greek cultural influence: when technical criteria were misapplied, when ordinary objects were given fancy names, ${ }^{6}$ and when every other sentence was decorated with a hellenic flourish, then it was time to call a halt (Rudd 1986:170)-and this task was undertaken with various degrees of enthusiasm by the satirists. As the symposium and the gymnasium became more popular in Rome, these aspects of Greek culture also posed problems: although singing and dancing were pleasant as entertainment, no gentleman would have dreamed of performing-that was for slaves and freedmen. Greek exercises were acceptable although it did not equal Roman military training, but gymnasiums did tend to attract homosexuals. Very often a symposium was merely an excuse for gluttony and drunkenness.

Cato the Censor, although he respected the Greeks of the past and knew Greek literature quite well, was convinced that the modern Greek race was "utterly depraved and undisciplined" (nequissimum et indocile) and that all of them should be expelled from Italy (Pliny $H N 7.113,29.14$ ). Such a degree of hostility was extreme. Undoubtedly most educated people had mixed feelings, valuing the skills of the Greeks and the culture which they represented, admiring and liking certain individuals, and yet distrusting them en masse as corrupt and unreliable.

Although Lucilius probably shared some of these misgivings about the Greeks, he generally seems to have taken a favourable view: if the Romans became debauched by Greek habits and institutions instead of using them to enhance the quality of life, that was largely their own fault, and they deserved what they got. In the surviving passages from Lucilius there is no condemnation of the Greeks as a people: where an individual is concerned, he is satirised as a rogue, not as a Greek (Rudd 1986:170).

When Horace started writing satire, he knew that although Varro had linked Lucilius with Old Comedy, the genre was really a Roman creation (Sat. 1.10.48; 2.1.63), and that this seemed to have linguistic consequences. Greek continued to be used in conversation and personal correspondence: even Augustus used Greek expressions for liveliness and wit. Undoubtedly Horace did the same, but where satire was concerned he had a different approach, maintaining that although satire used the informal tone of conversation, it was nevertheless a purely Roman literary genre; it should therefore be written in Latin (Rudd 1986:171).

However, this does not mean that the Sermones are totally free of Greek words or derivatives: the great majority of Horace's hellenisms had become naturalised and were no longer felt to be foreign (Rudd 1986:173). Consequently, contemporary Greeks play little part in Horatian satire and only a few faintly derogatory references are made to Greeks (Rudd 1986:176): the Sermones therefore seem to be rooted in a Graeco-Roman environment.

6 For example in 14 and 15f. Lucilius describes people who pretentiously called water-pots arutaenae ("pots à eau") instead of aquales; the legs of a couch clinipodes ("pieds de lit") instead of pedes lecti; and lamps lychni ("chandeliers") instead of lucernae (Rudd 1986:169). 
When Persius insists that he is using "words of the toga" (verba togae, 5.14), he seems to mean language that is in everyday use in Rome and vocabulary that is primarily Roman and not Greek: the mixture of idiom and vocabulary found in the satires is the healthy combination that characterizes earlier Roman satire, and Persius draws much from the colloquial language of the city. The satires indeed leave the impression that Persius avoided Greek vocabulary, for he uses such words sparingly, usually limiting himself to those which had by this time made their way into the everyday language of Rome (Ramage 1974:131). In fact, although several hellenisms appear in the prologue as well as in Satire 1, throughout his satires Persius uses only twelve Greek derivatives (see Wehrle 1992:71-77).

With Juvenal the picture changes dramatically. In Sat. 3.60-61 we read: non possum ferre, Quirites, Graecam urbem ("I cannot bear, fellow citizens of Rome, a Greek capital!"). For the first time in Roman satire Greeks are abused for being Greek and living in Rome, regardless of the fact that their presence was not illegal and that many of their ancestors had not come there of their own free will (Rudd 1986:184).

But let us get back to the satires of Persius. By using a striking concentration of hellenisms in his prologue Persius strongly criticises poets who seek inspiration from the Muses and who write poetry in the foreign Greek tradition:

Nec fonte labra prolui caballino

nec in bicipiti somniasse Parnaso

memini, ut repente sic poeta prodirem.

Heliconidasque pallidamque Pirenen

illis remitto quorum imagines lambunt

hederae sequaces; ipse semipaganus

ad sacra vatum carmen adfero nostrum.

quis expedivit psittaco suum "chaere"

picamque docuit nostra verba conari?

magister artis ingenique largitor

venter, negatas artifex sequi voces.

quod si dolosi spes refulserit nummi,

corvos poetas et poetridas picas

cantare credas Pegaseium nectar.

I never drenched my lips in the nag's fountain, nor dreamed, as far as I can remember, on two-peaked Parnassus so that I should thus come suddenly forth as a poet. The maidens of Mount Helicon and the blanching Pirene I leave to those men who have ivy clinging to their busts; it is as a half-member that I bring my song to the holy rites of the bards.

Who made it so easy for the parrot to squawk his "hello"? Who taught the magpie to ape the speech of man? It was that master of the art, that donor of genius, the belly, who is skilled in producing words which are not his own. If 
only the hope of deceitful money were to flash upon them, you would believe that raven poets and magpie poetesses were singing the nectar of Pegasus' spring.

The prologue is divided into two equal parts (1-7 and 8-14), linked by the motif of Pegasus which appears in the first and last lines. The first half deals with Persius himself as a writer of satire and the second half with poets in general. These two halves are linked by the theme of poetic inspiration. In the first half the underlying theme is divine inspiration, and in the second poetic inspiration provided by monetary gain. Persius refuses to pay lip-service to the traditional metaphors of poetic inspiration. The Muses, the Greek goddesses of poetry, were said to inhabit Hippocrene, the fountain (fonte ... caballino, 1) on Mount Helicon opened by a stroke of Pegasus' hoof. Mount Parnassus (2) was sacred to Apollo, the patron of poetry. Drinking (prolui, 1) from the fountain of the Muses as well as dreaming (somniasse, 2) on Mount Parnassus was a traditional metaphor for poetic inspiration. ${ }^{7}$ (Note that in line 4 Heliconides, i.e. the Muses, is given the Greek accusative ending Heliconidas, and so is Pirenen, the spring near Corinth where Pegasus was broken in.)

Although Persius does not identify the poets who have undergone these rituals of consecration, they undoubtedly include Ennius, who described how he had fallen asleep on the mountain of the Muses and how the soul of Homer had transmigrated to him (Ann. 1.2-5). ${ }^{8}$ Persius' rejection is carried further when he suggests that a dream like that of Ennius about Homer can be forgotten-nec in bicipiti somniasse Parnaso / memini (2-3) -and thus denies for himself any inspiration by the Muses.

The satirist therefore rejects the motif of the poet receiving his poetic initiation from divine sources, not only because it denies conscious craftsmanship and the hard work that goes into writing poetry (ut repente sic poeta prodirem, 3) but, equally important, because it is of Greek origin. His disapproval of the Greek tradition is already apparent when, in the first line, he calls the Hippocrene fountain fons caballinus. By Persius' time caballus was becoming normal in popular or vulgar speech and equus was the upper-class or literary word. ${ }^{9}$ By using the vulgarism Persius thus derides epic pretensions.

Persius ends the first half of the prologue with a positive statement: ipse semipaganus / ad sacra vatum carmen adfero nostrum (6b-7). He uses the

7 See Propertius 3.3.5 and Cicero Acad. Pr. 2.16.51 for the legitimate methods of securing inspiration.

8 This is also alluded to by Persius in 6.10-11. Persius' pointed rejection and criticism of the "dream on Helicon" as divine intervention by Muses for poets is directed not only at the tradition of the Muses appearing to Hesiod on Helicon (Theog. 22ff.), but also at that custom which was subsequently maintained by e.g. Callimachus (Aet. 1), Ennius and Propertius 3.3. By renouncing Helicon, Persius at once defines his own (poetic) status and initiates an aggressive invective against those of his contemporaries who might pretend to some degree of traditional (divine) poetic inspiration (Rudd 1986:179; Wehrle 1992:5).

9 Scholiast: caballino autem dicit, non equino, eo quod satyrae humiliora verba conveniant. 
traditional term vates for inspired poets ${ }^{10}$ and adapts the common metaphor of the poet's calling as a sacred ritual not to indicate that he is unqualified or unworthy of writing poetry, but to divorce himself deliberately from the traditional class of poets (Wehrle 1992:6-7). He is semipaganus ("half-initiated") because he cannot fully participate in the poets' mysteries as he does not share the divine inspiration of the epic and lyric writers, ${ }^{11}$ but draws his inspiration from the everyday world of the common man. ${ }^{12}$ Persius dissociates himself not only from the famous Greek poets and from the early Roman poets like Ennius who imitated Greek models (1-6a), but (in the second half of the prologue) also from his contemporaries who are inspired by monetary gain and who are slavishly continuing with the imitation of traditional epic and tragedy (8-14).

Greek also plays a part here. The parrot (psittacus, 8) is taught to say, not ave or vale, but chaere. ${ }^{13}$ In line 13 poeta had long been acclimatised, but poetrides is a new creation. Finally, nektar (14) is, of course, the Greek $\nu \varepsilon ́ \kappa \tau \alpha \rho$, but its epithet Pegaseium is a satirical coinage (Rudd 1986:179).

One reference in the prologue, however, serves as an important introduction to the discussion of Satire 1. The phrase poetridas picas or "magpie poetesses" in line 13 recalls the story (Ovid Met. 5.300ff., 664ff.) of how the nine daughters of Pierus challenged the Muses and, on being defeated, were turned into magpies. The reference is entirely appropriate as the story is told on Mount Helicon to Athene, who has come there to see the new spring created by the hoof of Pegasus (Rudd 1986:179-180).

Apart from the actual sentiments expressed by the hellenisms and Greek references in the prologue, this is an indication that Persius also uses Greek mythology as a structural background for his criticism. The story of Pierus' daughters provides an important link with Satire 1 where this approach is more clearly illustrated.

In Satire 1, as in 5.1-18, the criticism of modern poetry is connected with Persius' moral preaching, but the implications are much wider. It employs the contest of Pan and Apollo and the unfortunate decision of King Midas, giving the satire a quasi-mythical framework.

To understand that framework, we have to remember that in Greek mythology King Midas showed his incompetence as a judge of literature by declaring Pan superior to Apollo. As a punishment he was given ass's ears. With the aid of a turban he managed to conceal his ears from everyone except his barber. The latter,

For a more detailed discussion of the meaning of vates, see Zietsman 1988.

The scholiast remarks pagani dicuntur rustici qui non noverunt urbem.

This claim is repeated in 5.14, verba togae sequeris.

13 The parrot and the magpie are well-known imitators. For the practice of keeping parrots and magpies in great houses, see Pliny H.N. 10.117-120; Martial. 14.73, 76; Petronius 28.9, super limen autem cavea pendebat aurea, in qua pica varia intrantes salutabat. Besides being an imitator, the crow is a symbol of foolish pretension, the character in which it appears in one of Aesop's fables. 
bursting with the secret, whispered it into a hole in the ground. In Sat. 1.8 Persius reveals that he knows a terrible truth: nam Romae quis non-a, si fas dicere ("For who in Rome does not have-if only I could say it").

This truth will finally (1.121) turn out to be the fact that everyone in Rome has ass's ears. It would be dangerous to make this public, so Persius decides to bury his secret in his book (hic tamen infodiam, 1.120).

Within this framework, the theme of Persius' rejection of contemporary poets and their poetry is worked out at great length. The corruption of contemporary literature is shown to be inextricably linked to moral corruption, and again Persius uses Greek words and references to Greek literature to underline literary affectation and moral decay (Ramage 1974: 117; Rudd 1986:180-182). We find unfavourable comment on Attius' Iliad (Sat. 1.50-51), on tragedy (1.67-68), on elegy (1.51-52), and on epyllion or romantic epic $(1.34,93-95,99-102)$; scorn is directed at recitations and improvisations of wealthy Romans around the dinner table (1.51-52); and particular reference is made to the drivel written about Attis and the Bacchanals $(1.93,101,105)$.

But let us look more closely at the most important passages revealing the literary affectation and moral decay of the poetry Persius is criticising, starting with Sat. 1.15-18:

scilicet haec populo pexusque togaque recenti et natalicia tandem cum sardonyche albus sede leges celsa, liquido cum plasmate guttur mobile conlueris, patranti fractus ocello.

On your birthday you will finally read this stuff from a public platform, carefully combed, in a new white toga, flashing a gem on your finger, rinsing your supple throat with a clear preparatory warble, your eyes swooning in ecstasy.

The falseness of contemporary poetry becomes apparent as the poet-reciter flashes his ring (sardonyche, 1.16) and rinses his throat with a warbling sound (liquido cum plasmate, 1.17). The Greek words sardonyche $(\sigma \alpha \rho \delta \dot{o} \nu v \xi)$ and plasmate $(\pi \lambda \dot{\alpha} \sigma \mu \alpha)$ with their foreign phonology stress the alien character of the reciter who is in fact alien to the point of perversion (Wehrle 1992:72), for he is described as having "eyes swooning in ecstasy" (patranti fractus ocello, 1.18). This description of the performance of the poet reciting his work to an audience points to the effeminate quality of contemporary poetry.

In 1.32-35 Persius deals with the themes of elegy. The poet-reciter is the same effeminate type as before. He is wrapped in a hyacinth mantle (hyacinthina laena, 1.32 ) and his recitation is affected:

hic aliquis, cui circum umeros hyacinthina laena est, rancidulum quiddam balba de nare locutus

Phyllidas, Hypsipylas, vatum et plorabile siquid, eliquat ac tenero subplantat verba palato. 
Then someone with a purple mantle round his shoulders mumbles some insipid trash through his nose, filtering out a Phyllis or Hypsipyle or some other dolorous theme, and letting the words drip daintily over his palate.

(Sat. 1.32-35)

The plural words Phyllidas and Hypsipylas (34) are used contemptuously and refer to the sentimental subjects from mythology such as those treated by Ovid in Heroides 2 and 6, dealing with the love of a mythological heroine. ${ }^{14}$ Poetry is metaphorically seen as food dished up at a banquet. The "poetic food" is called rancidulum (33), a word which carries a strong negative connotation: 15 with reference to food, see Horace Sat. 2.2.89, rancidum aprum and Juvenal 11.134135 , absonia ... / rancidula. ${ }^{16}$ Persius' diminutive here expresses total contempt (Wehrle 1992:73). As far as he is concerned, poetic activity is an affectation, and its practitioners and its admirers are no more than effeminate frauds (Morford 1984:33).

In $1.93-95$ Persius turns to the Alexandrian tastes which survived in the early empire:

cludere sic versum didicit "Berecyntius Attis" et "qui caeruleum dirimebat Nerea delphin", sic "costam longo subduximus Appennino."

That is how "Berecynthian Attis" has learned to round off a line, and "the dolphin that divided dark blue Nereus", or "we stole a rib from the lengthy Apennine".

The tale of Attis, Cybele's favourite who castrated himself after breaking a vow of chastity, was morbid and un-Roman (see Catullus 63). The adjective Berecyntius (of Mount Berecyntus in Phrygia, sacred to Cybele) contains the Greek $\gamma$ which sounded sweet and exotic to Roman ears (Quintilian 12.10.27) and with Attis it formed a metrical pattern which Persius regarded as affected. ${ }^{17}$ In 1.94 the word order is reminiscent of neoteric epyllion (Nisbet 1963:46). Delphin is a later form of the Greek $\delta \varepsilon \lambda \phi i s$. The metonymy Nereus for mare and especially in the Greek accusative form Nerea as the object of dirimebat sounds grotesque-the divinity is being cut in two: both Nerea and delphin are obviously repugnant to Persius

14 Harvey $(1981: 27)$ points out that Persius probably does not have Ovid in mind here since "heroines are favoured poetic material. Moreover, the specimens of poetry cited at 93-95 and 99-102 suggest a continuing tradition of Ovidian practices, and it seems reasonable to postulate the post-Augustan existence of amatory poems written in the manner of Ovid".

15 Lewis and Short, s.v. II: "disgusting, loathsome, offensive". See also Martial 7.34.7, qui sic rancidulo loquatur ore.

16 Bo (1969) ad Persius 1.33 explains rancidulum as follows: carmen quoddam putidum, fastidium afferens, ineptum.

17 Ovid had used Cybeleius Attis (Met. 10.104) and Berecyntius heros (Met. 11.106). 
(Harvey 1981:44). Finally, quadrasyllabic endings, like Appennino, were typical of the neoterics (see Catullus 64). Quintilian quotes this very example (9.4.65) and calls the effect praemolle ("over-effeminate").

These Greek words serve as condemnation of the contemporary poets who accuse the Aeneid of frothiness (Wehrle 1992:73), for by way of contrast Persius quotes the opening words of the Aeneid in 1.96: poetry such as arma virum is now despised as old-fashioned-and naturally so, for as these two words make clear, it is essentially virile (Rudd 1986:181).

Even worse is to come as the contemporary poet continues in 1.99-102 with something that he regards as "fresh, and good for reciting with a languid neck" (quidnam igitur tenerum et laxa cervice legendum? 1.98):

"torva Mimalloneis inplerunt cornua bombis, et raptum vitulo caput ablatura superbo

Bassaris et lyncem Maenas flexura corymbis euhion ingeminat, reparabilis adsonat echo."

"They filled their frightening horns with Bacchanalian brays, and the Bassarid carrying the head torn from a frisky calf, and the Maenad, ready to guide the lynx with reins of ivy, cry 'Euhoe! Euhoe!' while the responsive echo chimes in."

The string of Bacchic clichés, namely the blowing of the horn, the tearing apart of cattle, the presence of the lynx and ivy, and the cry of "euhoe", paints a wild and outlandish scene, while the sound effect is consciously musical and the vocabulary markedly Greek. Nothing needs to be said about bombis, Bassaris, lyncem, Maenas, corymbis, euhion, and echo; but the adjective Mimalloneus is unparalleled. ${ }^{18} \mathrm{It}$ comes from the Greek noun Mimalloon, a Bacchante, which in turn is derived, according to the scholiast, from the imitation (mimesis) of Bacchus (Rudd 1986:181). Note how Persius also objects to the successive future participles ablatura and flexura, perhaps regarding them as a "modernistic" affectation (Harvey 1981:46). ${ }^{19}$

The poetic pretence to which Persius objects in this satire reveals emasculation to such an extent, even on the part of its creator, that Persius calls out: haec fierent si testiculi vena ulla paterni / viveret in nobis? (1.103-104, "Could such things happen if any of our fathers' virility still lived in us?"). Therefore, the satirist now digs himself a hole, and breathes into it the deadly secret that he has been carrying since the beginning of the poem:

hic tamen infodiam. vidi, vidi ipse, libelle:

auriculas asini quis non habet?

18 Ovid Ars am. 1.541 has the noun Mimallonides.

19 Harvey (1981:45) identifies an unusual tricolon in these lines: the second colon is elongated and the third strikingly brief, so that the sentence tails off feebly, indicating Persius' objection to this weak and affected structure. 
I'll bury it here. I saw it, yes I saw it, my book, with my own eyes: who hasn't got the ears of an ass?

According to the ancient biographer, Persius originally wrote auriculas asini Mida rex habet ("King Midas has the ears of an ass"); the change was made after his death to avoid offending Nero. Rudd (1986:68), however, argues that Persius did write auriculas asini quis non habet and that someone later wrote Mida rex either in the margin or above quis non so as to remind the reader of the fable in question. This double tradition was known to the scholiast and the biographer and they reversed the process, maintaining that the reading Mida rex was changed either by Persius himself or by Cornutus. The reading quis non is, however, supported by the poet's initial uncompleted question in 1.8, nam Romae quis non-a, si fas dicere ("For who in Rome does not have-if only I could say it"). ${ }^{20}$ It is also more effective if everyone in Rome is indicted, not merely Nero or a type (Harvey 1981:51). Yet, Persius was still taking a risk: literary critics should not say that the emperor has. no clothes at a time when the reigning emperor writes poetry (Nisbet 1963:48).

But, like Midas' barber, only Persius has seen Rome's asininity, and this is his final condemnation of Rome's taste and morals: no one has any taste. The conclusion of the Midas story, as given by Ovid in Met. 11.190-193, was that the reeds heard the barber's secret and passed it on. In Persius' case, however, his secret will not receive the same sort of furtive publicity, for he adds:

hoc ego opertum

hoc ridere meum, tam nil, nulla tibi vendo

Iliade.

This is my secret, this is my joke. Slight as it is, I wouldn't sell it for all your lliads.

$$
(1.121-123)
$$

This, then, is the mythological framework for Persius' satire. His discovery of the rottenness of contemporary standards is a secret, yes, but, as the wind blowing through the reeds whispered Midas' secret, Persius' secret will be shared with those few who appreciate the honest criticism of the satirical tradition (Ramage 1974:118). They are the readers addressed in 1.123-125:

audaci quicumque adflate Cratino iratum Eupolidem praegrandi cum sene palles, aspice et haec, si forte aliquid decoctius audis.

20 Nisbet (1963:48) argues that it is just possible that 1.8 was changed as well. He seems to support the reading Mida rex, stating: "This might have some truth in it, for it is easier to bury a statement than a question." 
If you have caught the spirit of brave Cratinus, or are pale from devotion to angry Eupolis and the Grand Old Man, if you have an ear for a concentrated brew, have a look at this.

In this passage Persius describes the sort of reader he wants: one who has studied Cratinus, Eupolis, and Aristophanes, the writers representing Old Comedy, i.e. the kind of writing which treats life in an entertaining style and a spirit of moral candour (Rudd 1986:122; 182). ${ }^{21}$ By implication Persius is promising his readers outspoken criticism of contemporary personages and events (Wehrle 1992:34), but for material such as this he requires a reader with sound judgement and good taste-" with ears well steamed by comic vinegar" (vaporata lector mihi ferveat aure, 1.126).

Satire 1 ends with the poet's rejection of those readers who have a low-witted mentality:

inde vaporata lector mihi ferveat aure, non hic qui in crepidas Graiorum ludere gestit sordidus et lusco qui possit dicere "lusce", sese aliquem credens Italo quod honore supinus fregerit heminas Arreti aedilis iniquas, 130 nec qui abaco numeros et secto in pulvere metas scit rasisse vafer, multum gaudere paratus si cynico barbam petulans nonaria vellat. his mane edictum, post prandia Callirhoen do.

I want a reader with his ears well steamed by that comic vinegar, not the lout who is eager to jeer at Greek sandals, and is willing to shout "hey, one-eye!" at a man with that affliction, who thinks he's somebody just because as Aedile at Arezzo he has smashed a few short measures with full municipal pomp, nor the witty fellow who sniggers when he sees numbers and cones traced in the sand of the abacus, and is vastly amused if a Nones-girl has the impudence to pull a philosopher's beard. For them I suggest the law reports in the morning, and Callirhoë after lunch.

$$
(1.126-134)
$$

Since the ears of these base-humoured readers are not steam-cleaned, their laughter is aroused by such simple-minded amusements as odd shoes (crepidas Graiorum, 1.127) or facial mutilation (lusce, 1.128). They represent foolish, self-important holders of insignificant office (honore supinus ... aedilis, 1.129-130): politicians of this kind provided perfect targets for Old Comedy since they were by nature devoid of the slightest consciousness of a philosophically sound view of the world. Likewise, the anti-intellectual who laughs at mathematical calculations and

21 So, not all Greek poetry was corrupt, for Persius makes an exception of Comedy. New Comedy was also acceptable, as appears from the scene in 5.161-174. Menander was close to life in style and subject; he could also be admired as a critic of human follies (Rudd 1986:181). 
geometrical figures described on a sand-table (abaco numeros et secto in pulvere metas, 1.131) and who applauds when an impudent girl is rude to a cynic preacher (cynico, 1.133) is not able to appreciate Persius' satire (Wehrle 1992:35-36).

The right entertainment for such provincial philistines (his, 1.134) is the edictum in the morning (probably a law-report or play-bill) and Callirhoe after lunch. Since the whole satire has been about literature, it seems best to regard Callirhoe as the heroine of some romantic piece without moral-intellectual content (Rudd 1986:181-182; see also Wehrle 1986:36).

This final scornful rejection of those mentalities incapable of appreciating his literature, this outright dismissal of those undeserving of his satires, underlines the poet's dislike of most types of Graeco-Roman poetry, the only exception being Comedy. But we also note here that when Persius defends Greek culture against ignorant mockers, he is thinking of Graeco-Roman philosophy.

In this defence the centuriones (the archetype of the non-philosopher) are presented as exempla of ignorance and boorishness. In 3.77-84 a smelly centurion (gente hircosa centurionum) reacts with contempt to the poet's sermon against laziness and his exhortation to study philosophy (see i.a. Harvey 1981:98; Wehrle 1992:56). At the end of Satire 5 (189-191) another centurion laughs vulgarly at Persius' words and offers a clipped hundred-as-piece for a hundred Greek philosophers:

dixeris haec inter varicosos centuriones, continuo crassum ridet Pulfenius ingens et centum Graecos curto centusse licetur.

Say this among the varicose centurions and huge Pulfenius bursts into a crass guffaw, bidding a clipped hundred-as-piece for a hundred Greeks.

The startling detail of varicosos ("with varicose veins") is contemptuous and intended as a piece of personal abuse. The attitude of Pulfenius (a fairly common name) is similar to that of the man who laughed at Greek sandals (crepidas Graiorum, 1.127); he is therefore used as a representative of the ignorant majority of ordinary Romans who do not care about Stoic doctrines.

This, then, points to Persius' other main involvement with Greece, namely Stoicism. Although his involvement with Stoicism falls beyond the scope of this paper (see i.a. Rudd 1986:182), this might provide the answer to one aspect of his multiculturalism not treated so far.

\section{Persius on Jews}

Although the negative treatment of Greeks runs right through the whole line of Roman satirists, the poems of Juvenal culminate in another dimension: outspoken anti-Semitism. Although Coffey (1976:138) argues that Juvenal tempered his denunciation of Jews since very few of them were of social importance, he vehemently despised their way of life and its influence on Roman traditions (see for 


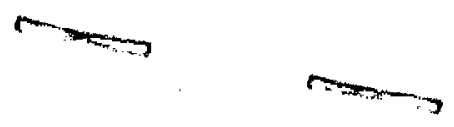

example Sat. 3.12-16, 3.296, 6.156-160, 6.542-547, 8.160 and 14.96-106): the Jews with their superstitions cast out Egeria and the Camenae from their grove, they lived by begging and fortune-telling, and made Romans despise their own laws in favour of the Jewish Law (Courtney 1980:27 et ad locc.).

Against the political and social background of Rome in the first century A.D. this development is not strange: even Horace made jokes about the superstitious Jews. His numerous references evidently imply that Judaism was spreading and was discussed among the governing class, if not favoured by them (Conington 1874:119; see also Sherwin-White 1967:86-87, 90, 96). The hostile account of a Roman convert's son in Juvenal 14.96-106 gives the same impression although he also brings in the theme of anti-social separatism. Juvenal's criticism and dislike echo the attitudes expressed by Tacitus Hist. 5.4-5 who seems to approve of nothing that he mentions about the Jews (Sherwin-White 1967:97-98): there is an overall impression of poverty and meanness, summarized in Tacitus' final remark: Iudaeorum mos absurdus sordidusque- "the Jewish custom is pointless and mean".

This was the private and unofficial opinion in Rome, but what was the attitude of the Roman administration? Both Tiberius and Claudius expelled large numbers of Jews (Tacitus Ann. 2.85.5; Suetonius Claud. 25.3) although they soon returned to Rome. Claudius, who also had to deal with difficulties that had arisen in Judea itself and even at Rome as a result of the folly of the emperor Gaius who tried to impose the imperial cult upon the Jews, remained suspicious of some aspects of Jewish activity (Sherwin-White 1967:90, 96). Nevertheless, the imperial government maintained a general philo-Judaic attitude. Augustus reaffirmed the privileges of the Jews in the Greek cities of Asia after complaints of persecution were made during his reign, and also provided severe penalties against those who stole sacred books and money from the synagogues (Josephus $A J$ 16.6.2, 4, 5). In this climate of, on the one hand, hostile private criticism and, on the other, official tolerance of a large irritating resident population, why, then, does Persius mention Jews only once in Satire 5?

\section{quid pulchrius? at cum \\ Herodis venere dies unctaque fenestra \\ dispositae pinguem nebulam vomuere lucernae \\ portantes violas rubrumque amplexa catinum \\ cauda natat thynni, tumet alba fidelia vino \\ labra moves tacitus recutitaque sabbata palles.}

But when Herod's birthday arrives, and the lamps with their violets, placed on the greasy window-sills, spew out heavy clouds of smoke, and when the tunny's tail swims around, encircling the cheap red dish, and the white jar bulges with wine, you move your lips in silence and blanch at the circumcised Sabbath.

$$
\text { (5.179-184) }
$$

In these lines Persius deals with the enslaving power of religious superstition. Some scholars (e.g. Lee \& Barr 1987:154) incorrectly argue that the poet's Jewish 
references are imprecise and difficult to identify, but although Persius is unlikely to be closely acquainted with Judaism, he is clearly thinking of the Sabbath in this passage (see Harvey 1981:176-178): dies (5.180) is plural either because the Sabbath affects two days, or because it is seen as a continuing series of festal days recurring weekly. Persius sneers at the lighting of lamps in the greasy windows (uncta fenestra, 5.180) just before the start of the Sabbath (Jews were forbidden to kindle fires on the Sabbath itself, Exodus 35:3), he derides the poverty of the Jews using cheap tableware (rubrum ... catinum, 5.182) to eat their inferior food (cauda ... thynni, 5.183), and hints at the undesirable connotations of silent prayer cloaking evil intentions (labra moves tacitus, 5.184).

The epithet recutita ... sabbata (5.184) mentions the Jews' best-known and most-mocked physical feature, and finally palles probably indicates the unreasoning fear of the superstitious man on festal days (as opposed to the faith of the religious man). Alternatively, palles may imply a "sympathiser" or partial proselyte (see Juvenal 14.96; Martial 7.30.5), which would give this passage another dimension: the Jews in Rome are probably not Persius' only target, for their religious customs had been widely adopted by gentiles. The possible subject of these lines may well have been a Roman convert to Judaism: a case of the conversion of a noble Roman lady to Judaism in the reign of Tiberius is mentioned by Josephus $A J$ 18.3.4 (Conington 1874:119).

But, although these lines (as well as 5.185-188, referring to both the cults of Cybele and Isis and ignorant Roman superstitions) are indeed deliberate criticism of the foreign religions of his day, Persius' motive here differs from his outspoken criticism of Greek literature: it should be remembered that Satire 5 expounds the Stoic paradox that only the wise man is free, and all fools are slaves (Cicero Par. Stoic. 5). The point here is that superstition is a worse form of slavery than political ambition treated in the preceding lines (5.176-179). The transition is brought about by the sarcastic quid pulchrius? in 5.179 which should actually be understood as quid peius?, "what could be worse (that is, than ambition)?"-and the answer: "superstition!” (see Lee \& Barr 1987:154-155).

This approach corresponds with the philosophical thought of Persius' time. The educated upper class in Rome reacted to the excesses of Nero by turning to philosophy and mostly to Stoicism. Roman Stoicism during the Neronian era emphasized the dignity of the individual and therefore made freedom a central theme: if political freedom were curtailed, personal freedom could still be asserted (Morford 1984:10). This teaching drew its strength from the basic Stoic doctrine that physical and temporal goods such as wealth, health, and comfort cannot affect virtue, that is above all and primarily important to a human being. Persius, who was not involved in public life and who had no motivation to write political satire (although 1.107-121 hints at the possibility), directed his Stoic doctrines to the ethical side of Roman society: Satire 1 explores the connection between morality and literature, and Satire 4 that between self-knowledge and honesty in public life, while Satire 5 examines freedom in the context of personal morality, and the other satires 
deal with standard moral themes, exhorting the reader to follow the precepts of philosophy (Morford 1984:11-12).

In conclusion, therefore, although Persius uses Greek references in his rejection of most types of Graeco-Roman poetry, his reference to Judaism does not fall in the same category. He is not criticizing Jews for being Jews or for their negative influence on Roman society as Juvenal does; he is not affected by their alien ways or threatened by their presence-the Jewish colony was only one of many alien sects in Rome-but he uses Judaism as an example of moral slavery in a context of moral freedom. This overwhelmingly moral emphasis is in line with the doctrine of Roman Stoicism, teaching that virtue is more important than physical and temporal benefits, and that passions, such as anger and fear, are to be suppressed. For Persius, these passions include avarice, luxury, slavery to sex, ambition, and superstition as symbolized by Judaism.

\section{BIBLIOGRAPHY}

Bo, D 1969. A. Persi Flacci saturarum liber. Torino: Paravia.

Clausen, W V 1968 [1959]. A. Persi Flacci et D. Iuni Iuvenalis saturae. Oxford: Clarendon.

Coffey, M 1976. Roman satire. London: Methuen.

Conington, J \& Nettleship, H 1874. The Satires of A. Persius Flaccus. Oxford: Clarendon.

Courtney, E 1980. A commentary on the Satires of Juvenal. London: Athlone Press. Harvey, R A 1981. A commentary on Persius. Leiden: Brill.

Jenkinson, J R 1980. Persius: The Satires. Warminster: Aris \& Phillips.

Lee, G \& Barr, W 1987. The Satires of Persius. Liverpool: Francis Cairns.

Morford, M 1984. Persius. Boston: Twayne.

Nisbet, R G M 1963. Persius. Critical essays on Roman literature: Satire (ed. J P Sullivan). London: Routledge \& Kegan Paul.

Ramage E S et al. 1974. Roman satirists and their satire: The fine art of criticism in ancient Rome. New Jersey: Noyes.

Rudd, N (tr) 1973. The Satires of Horace and Persius. Harmondsworth: Penguin.

Rudd, N 1986. Themes in Roman satire. Norman and London: University of Oklahoma Press.

Sherwin-White, A N 1967. Racial prejudice in imperial Rome. Cambridge: University Press.

Wehrle, W T 1992. The satiric voice: Program, form and meaning in Persius and Juvenal. Hildesheim: Olms.

Zietsman, J C 1988. Persius and the vates concept. Akroterion 33:71-78. 